Original Paper

\title{
Peningkatan Hasil Belajar Matematika melalui Media Pembelajaran Segitiga Bongkar Pasang dengan Strategi STAD
}

\author{
Dedi Setiawan ${ }^{1^{*}}$ \\ 1 Sekolah Menengah Pertama Negeri 3 Lingsar, Kabupaten Lombok Barat, NTB, Indonesia
}

\section{DOI: https://doi.org/10.29303/jcar.v3i1.629}

${ }^{*}$ Corresponding Author: Dedi Setiawan, Sekolah Menengah Pertama Negeri 3 Lingsar, Kabupaten Lombok Barat, NTB, Indonesia. Email:

dsetiawan_smp3@gmail.com

\begin{abstract}
Abstrak: Penelitian ini bertujuan untuk memperkenalkan Segitiga Bongkar Pasang sebagai sebuah media pembelajaran materi Matematika untuk sekolah di daerah tertinggal seperti SMP Terbuka. Pembuatan media dilakukan untuk membuat pembelajaran lebih menarik dan realistis pada 15 Tempat Kegiatan Belajar (TKB) SMP terbuka Narmada I yang berinduk di SMPN 3 Lingsar seperti TKB Mandiri Montong Buwuh II. Jenis penelitian yang digunakan adalah Penelitian Tindakan Kelas dengan melibatkan 7 orang siswa kelas VII. Teknik pengumpulan data pada hasil belajar dengan memberikan tes evaluasi pada siswa setelah pembelajaran berlangsung di setiap siklus. Hasil penelitian menunjukkan bahwa dengan KKM 70, ketuntasan klasikal siswa pada Siklus I sebesar 28,6\% dan meningkat menjadi $85.7 \%$ pada Siklus II. Berdasarkan hal tersebut dapat disimpulkan bahwa penerapan media Segitiga Bongkar Pasang dengan strategi STAD dapat meningkatkan hasil belajar siswa.
\end{abstract}

Kata kunci: Media Segitiga Bongkar Pasang; Strategi STAD; Hasil belajar

\section{Pendahuluan}

Pendidikan merupakan usaha yang dilakukan oleh orang yang ddiberikan tanggung jawab untuk mempengaruhi peserta didik (Muhson, 2010). Pendidikan diharapkan menjadikan peserta didik mampu mencapai proses pendewasaan dan kemandirian menjadi lebih baik (Muhson, 2010).

Pendidikan juga merupakan bimbingan yang diberikan dengan sengaja oleh orang dewasa kepada anak-anak, dalam pertumbuhannya (baik jasmani maupun rohani) agar berguna bagi diri sendiri dan masyarakat (Sunain, 2016). Dalam arti lain, pendidikan merupakan pendewasaan peserta didik agar dapat mengembangkan bakat, potensi, dan keterampilan yang dimiliki dalam menjalani kehidupan (Sururuddin, 2016) . Oleh karena itu, sudah seharusnya pendidikan di desain guna memberikan pemahaman dan meningkatkan prestasi belajar peserta didik (siswa).

Rendahnya konsep belajar siswa di sekolah sering sekali dijadikan permasalahan belajar dari siswa tersebut dalam memahami materi (Triani, 2014). Indikasi ini dimungkinkan karena faktor belajar siswa yang kurang efektif, sehingga siswa sendiri tidak merasa termotivasi dalam mengikuti pembelajaran di kelas. Akibatnya, siswa kurang atau bahkan tidak memahami materi yang bersifat sukar, yang di berikan oleh guru tersebut. Kecenderungan pembelajaran kurang menarik ini merupakan hal yang wajar dialami oleh guru yang tidak memahami kebutuhan dari siswa tersebut, baik dalam karakteristik maupun dalam pengembangan ilmu. Jadi bukan hanya menerapkan pembelajaran berbasis konvensional. 
Pembelajaran yang baik dapat ditunjukan dari suasana pembelajaran yang kondusif (Setyosari et al., 2016). Karena dalam era perkembangan Iptek yang begitu pesat, profesionalisme guru tidak cukup hanya dengan kemampuan membelajarkan siswa, tetapi kegiatan belajar siswa (Ibrahim, 2001). Salah satu ciri guru yang profesional adalah bagaimana dirinya memilih strategi dan media pembelajaran yang tepat dalam setiap materi pelajaran yang diampunya. Ketepatan dalam menggunakan pendekatan pembelajaran yang dilakukan dapat mempengaruhi aktivitas dan prestasi belajar siswa pada proses pembelajaran. Pemilihan suatu metode pembelajaran hendaknya disesuaikan dengan materi pembelajaran, tingkat kecerdasan siswa, serta lingkungan dan kondisi setempat. Sebab waktu yang diperoleh siswa untuk belajar di tiap-tiap bidang studi sangat terbatas khususnya matematika.

Matematika merupakan salah satu dari bidang studi yang menduduki peranan penting dalam dunia pendidikan (Sholihah \& Mahmudi, 2015). Matematika merupakan subjek yang sangat penting dalam sistem pendidikan di seluruh dunia (Munzir, 2015). Negara yang mengabaikan pendidikan matematika sebagai prioritas utama akan tertinggal dari kemajuan segala bidang (terutama sains dan teknologi), dibanding dengan negara lainnya dengan memberikan tempat bagi matematika sebagai subjek yang sangat penting.

Ironisnya, dalam pelajaran matematika kesiapan serta keaktifan siswa cenderung masih rendah. Dalam proses pengamatan pendahuluan pembelajaran matematika yang telah dilakukan peneliti di kelas VII TKB Mandiri Montong Buwuh II SMP Terbuka Narmada I Kabupaten Lombok Barat ditemukan keragaman masalah tentang rendahnya keaktifan siswa, yaitu: (1) Kurangnya keberanian siswa dalam mengajukan pertanyaan; (2) Kurangnya keaktifan siswa untuk mengerjakan soal di depan kelas; (3) Kurangnya keberanian siswa dalam mengemukakan ide atau pendapatnya; dan (4) Rendahnya keaktifan siswa dalam menjawab pertanyaan dari guru. Hal tersebut dapat dilihat dari rata-rata nilai ulangan umum semester ganjil tahun pelajaran 2014/2015 kelas VII SMP Terbuka Narmada I yang berada di bawah Kriteria Ketuntasan Minimal (KKM) yaitu 56,67 dari nilai KKM yang ditetapkan oleh sekolah yaitu 75 .

Dari hasil observasi di atas, salah satu faktor penyebab rendahnya aktivitas dan prestasi belajar matematika siswa di SMP Terbuka Narmada I adalah kurang tepatnya metode dan media yang digunakan oleh guru dalam pembelajaran sehingga mengakibatkan: (1) kurangnya kreatifitas siswa dalam menemukan jawaban atau solusi terhadap masalah yang dihadapi selama pembelajaran berlangsung; (2) selama pembelajaran guru kurang memberikan kesempatan kepada siswa untuk menemukan sendiri cara penyelesaian masalah yang dihadapi selama pembelajaran berlangsung; (3) siswa jarang bertanya; (4) interaksi pembelajaran berkesan monoton dan didominasi oleh siswa yang pintar saja; (5) siswa takut untuk mengemukakan pendapatnya.

Berdasarkan uraian permasalahan di atas, maka keberadaan media dan model pembelajaran yang efektif dapat dijadikan alternatif untuk menanggulangi keadaan tersebut sehingga siswa dapat lebih aktif dalam pembelajaran. Media dan model pembelajaran yang dimaksud adalah model kooperatif dengan strategi STAD dengan menggunakan media Segitiga Bongkar Pasang.

Media Segitiga Bongkar Pasang merupakan media pembelajaran segitiga yang terbuat dari tiga buah penggaris kayu dan busur derajat. Media ini dapat dibongkar pasang sehingga dapat merubah besaran sudut dan panjang sisinya. Media ini akan diajarkan menggunakan strategi STAD. Penelitian ini mengkaji dan mendeskripsikan tentang Peningkatan hasil belajar Matematika pada siswa kelas VII TKB Mandiri Montong 
Buwuh II melalui media pembelajaran Segitiga Bongkar Pasang dengan Strategi STAD.

\section{Metode}

Pelaksanaan Pendekatan Tindakan Kelas (PTK) menggunakan pendekatan kuantitatif yang merupakan penelitian berupa angkaangka dan analisis yang menggunakan statistik. Pendekatan kuantitatif digunakan untuk mendapatkan data mengenai hasil belajar.Subyek penelitian ini adalah siswa kelas VII di SMP Terbuka Narmada I TKB Mandiri Montong Buwuh II berjumlah 7 orang pada semester genap tahun pelajaran 20152016.

Metode penelitian yang digunakan dalam penelitian ini adalah penelitian tindakan kelas (classroon Action Research). Penelitian tindakan kelas merupakan suatu proses yang memberikan kepercayaan kepada pengembang kekuatan berfikir reflektif, diskusi, penentuan putusan dan tindakan tindakan orang-orang biasa yang berpartisipasi dalam penelitian untuk mengatasi kesulitan-kesulitan yang mereka hadapi dalam kegiatannya. Rencana yang ditetapkan dalam Penelitian Tindakan Kelas menggunakan 2 siklus, masing-masing siklus terdiri dari perencanaan, pelaksanaan tindakan, observasi dan refleksi (Sukmadinata, 2005) seperti pada gambar 2 .

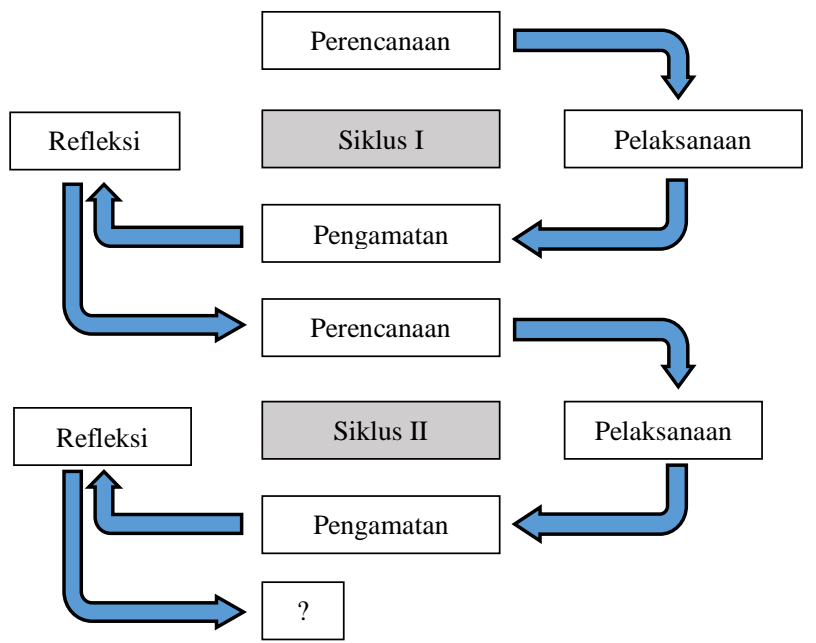

Gambar 2. Siklus Penelitian Tindakan Kelas.
Rancangan penelitian yang dimaksud disini adalah tindakan berupa tindakan aktivitas dan hasil belajar Matematika menggunakan media Segitiga Bongkar Pasang dengan strategi Kooperatif STAD. Fokus penelitian ini adalah untuk melihat apakah hasil belajar peserta didik meningkat jika dalam proses pembelajaran menggunakan media Segitiga Bongkar Pasang dengan strategi STAD. Kegiatan yang dilakukan dalam tahap ini adalah melaksanakan pembelajaran yang telah direncanakan sesuai dengan tujuan yang ingin dicapai yaitu meningkatkan hasil belajar siswa pada mata pelajaran Matematika Materi bangun datar Segitiga dengan strategi STAD. Untuk meningkatkan hasil belajar peserta didik sebagai bukti penuntasan permasalahan dalam pembelajaran digunakan tindakan berulang atau bersiklus yang terdiri dari perencanaan, pelaksanaan, observasi atau evaluasi dan refleksi.

1. Tahap I

a. Tahap perencanaan

Kegiatan-kegiatan dalam perencanaan kegiatan tindakan penelitian adalah menyusun program satuan pembelajaran, menyusun rencana pembelajaran dan menyusun instrumen penelitian.

b. Tahap pelaksanaan tindakan

Pelaksanaan pembelajaran disesuaikan dengan jadwal mata pelajaran Matematika di SMP Terbuka Narmada I TKB Mandiri Montong Buwuh II direncanakan dalam scenario pembelajaran.

c. Tahap Observasi dan Evaluasi

Pada tahap ini dilaksanakan observasi terhadap pelaksanaan tindakan. Observasi dilaksanakan selama proses pembelajaran sedangkan evaluasi hasil belajar dilaksanakan setiap siklus.

d. Tahap Refleksi Siklus I

Refleksi dilakukan setiap akhir siklus pembelajaran. Hasil yang didapatkan dikumpulkan dan dianalisis. Dari hasil analisis tersebut peneliti dapat merefleksi diri dengan melihat data hasil tes, apakah 
kegiatan yang telah dilakukan dapat meningkatkan hasil belajar peserta didik. Apabila dalam pelaksanaan pada siklus I belum berhasil atau belum sesuai dengan kriteria keberhasilan maka dilanjutkan pada siklus II.

\section{Tahap II}

Apabila refleksi siklus I memperoleh hasil kurang optimal maka pada siklus II perlu dilakukan perbaikan dari siklus sebelumnya. Perbedaan pada siklus II merupakan perbaikan dari siklus sebelumnya yang berdasarkan hasil refleksi. Pada siklus II tindakan yang dilakukan sama dengan siklus I dengan memperhatikan kekurangan pada siklus I.

Teknik pengumpulan data dari penelitian ini adalah dengan observasi terhadap kegiatan pembelajaran yang lebih difokuskan untuk mengetahui keterlaksanaan RPP selama proses pembelajaran. Catatan lapangan juga dilakukan untuk memperoleh data mengenai hal-hal yang tejadi selama proses pembelajaran berlangsung yang tidak tercantum dalam lembar observasi. Data hasil observasi aktivitas guru dalam keterlaksanaan RPP dianalisis menggunakan rumus sebagai berikut:

Keterlaksanaan RPP $=\frac{\mathrm{A}}{\mathrm{B}} \times 100 \%$

Keterangan :

A = Jumlah langkah pembelajaran yang terlaksana

$\mathrm{B}=$ Jumlah langkah pembelajaran yang direncanakan

Untuk mengetahui tingkat keterlaksanaan langkah pembelajaran, maka prosentase keterlaksanaan dicocokkan dengan kriteria yang dilihat pada Tabel 1.

Tabel 1: Pedoman Kategori Keterlaksanaan Pembelajaran

\begin{tabular}{ll}
\hline Interval & Kategori \\
\hline $80 \%-100 \%$ & Sangat baik \\
$60 \%-79 \%$ & Baik \\
$40 \%-55 \%$ & Cukup \\
$20 \%-39 \%$ & Kurang baik \\
$<20 \%$ & Tidak baik \\
\hline
\end{tabular}

Disamping itu dilakukan tes akhir pada setiap tindakan untuk mengukur hasil belajar Matematika dan tingkat keberhasilan pembelajaran tiap siklus. Tes merupakan prosedur yang digunakan untuk mengadakan penilaian yang berbentuk suatu tugas atau serangkaian tugas yang harus dikerjakan satu kelompok sehingga menghasilkan suatu nilai tentang keterampilan atau hasil belajar siswa tersebut yang dapat dibandingkan dengan nilai yang dicapai oleh siswa atau dengan standar nilai yang ditetapkan (Arikunto, 2011).

Hasil belajar dianalisis secara deskriptif dengan mencari ketuntasan belajar secara klasikal minimal $85 \%$ dari jumlah siswa yang memperoleh nilai 74 keatas yang dilihat pada hasil evaluasi tiap-tiap siklusnya. Persamaan ketuntasan klasikal adalah:

$$
\mathrm{KK}=\frac{x}{z} \times 100 \%
$$

Keterangan :

$\mathrm{KK}=$ Ketuntasan klasikal

$X \quad$ Jumlah siswa yang memperoleh nilai $\geq 75$

$z \quad=$ Jumlah siswa

\section{Hasil dan Pembahasan}

\section{Ide Dasar Media Segitiga Bongkar Pasang}

Berdasarkan hasil survei di SMP Terbuka Narmada I, pembelajaran materi bangun datar segitiga umumnya dilaksanakan menggunakan strategi pembelajaran langsung. Pemodelan segitiga hanya berupa gambar, dimana guru akan menggambar di papan tulis beberapa jenis segitiga. Penulisan sudut dan panjang sisi lebih banyak berdasarkan perkiraan dan intuisi guru yang telah menjadi sebuah kebiasaan. Terkadang guru membekali diri dengan penggaris kayu ukuran satu meter dan sebuah busur derajat yang juga terbuat dari kayu. Meskipun demikian, pelaksanaannya tetap hanya untuk menggambar di papan tulis.

Berdasarkan hal tersebut, penulis mencoba membuat sebuah segitiga dengan menyusun tiga buah penggaris yang disediakan oleh sekolah. Dengan mengkombinasikan posisi ketiganya, akan 
didapatkan berbagai jenis segitiga yang dapat digunakan dalam pembelajaran bangun datar segitiga yang meliputi: Jenis-jenis segitiga, Jumlah dan besar sudut segitiga, hubungan antara besar sudut dan panjang sisi pada segitiga, keliling dan luas segitiga.

\section{Proses Penemuan Media Segitiga Bongkar Pasang}

Dari ide dasar di atas, untuk memenuhi kebutuhan siswa dan guru akan media yang praktis. Menggunakan bahan yang murah dan ramah dan mudah di dapat. Media ini dirancang agar guru dapat membuat, berbagai jenis segitiga seperti segitiga siku-siku, segitiga sama kaki, segitiga sama sisi, segitiga sudut lancip, segitiga sudut tumpul atau beberapa jenis segitiga sembarang. Bahan yang digunakan adalah tiga buah penggaris kayu dan dilengkapi tiga pasang baut dan mur. Masing-masing penggaris pada kedua ujungnya dibuat belahan sehingga sambungan antar penggaris dapat digeser untuk mengatur panjang sisi atau besar sudut segitiga.

Melengkapi dari media ini, pada dua sudut segitiganya dilengkapi dengan busur derajat agar peserta didik dapat melihat langsung besaran sudut pada segitiga. Penempatan busur derajat juga bertujuan agar peserta didik dapat memahami penjumlahan sudut pada segitiga adalah $180^{\circ}$. Hal ini untuk pembelajaran sub materi jumlah dan besar sudut segitiga. Dalam pembuatan segitiga baut salah satu sudut di atur sehingga dua sisi pembentuk sudut tersebut dimulai dari titik 0 . Titik 0 adalah hasil kalibrasi ulang terhadap angka meteran pada sisi dalam penggaris. Angka meteran ini bertujuan agar peserta didik dapat menghitung panjang sisi pada sub materi hubungan antara besar sudut dan panjang sisi pada segitiga.

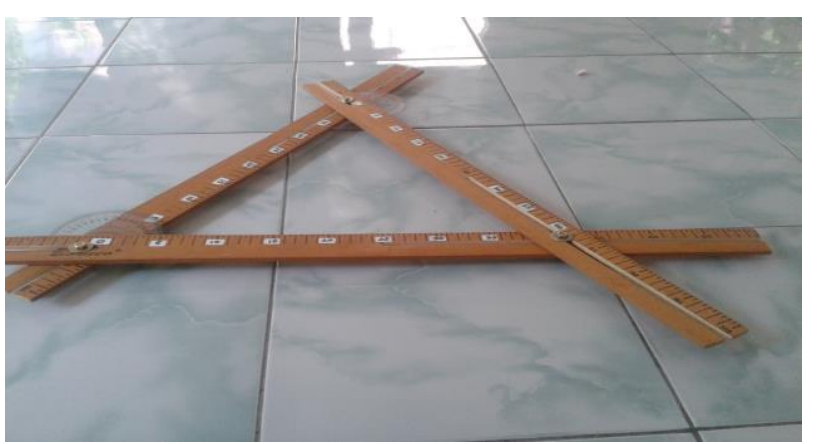

Gambar 1. Media Segitiga Bongkar Pasang

\section{Data Hasil Aplikasi Praktis Inovasi Pembelajaran}

Penelitian ini dilaksanakan pada tanggal 16 sampai 28 Mei 2016 pada siswa kelas VII tahun pelajaran 2015-2016 di SMP Terbuka Narmada I TKB Mandiri Montong Buwuh II Lombok Barat. Adapun materi yang diajarkan pada penelitian adalah Bangun datar Segitiga dengan mengimplementasikan media Segitiga Bongkar Pasang dengan strategi kooperatif STAD.

Pada siklus I, diberikan materi Jenis-jenis Segitiga ditinjau dari panjang sisi dan besar sudutnya dengan alokasi waktu 2×40 menit mengacu pada RPP yang disusun. Pada proses ini tidak berjalan dan tidak sesuai dengan RPP yang disusun karena waktu banyak terbuang dengan penjelasan materi dan guru mengambil peranan yang dominan.

Tabel 2. Data Hasil Keterlaksanaan kegiatan pembelajaran siswa kelas VII SMP Terbuka TKB Mandiri Montong Buwuh II.

\begin{tabular}{lll}
\hline Parameter & Siklus I & Siklus II \\
\hline $\begin{array}{l}\text { Jumlah langkah } \\
\text { terencana }\end{array}$ & 16 & 16 \\
$\begin{array}{l}\text { Jumlah langkah } \\
\text { terlaksana }\end{array}$ & 11 & 14 \\
$\begin{array}{l}\text { Persentase ketuntasan } \\
\text { Kategori }\end{array}$ & $68,8 \%$ & $87,5 \%$ \\
\hline
\end{tabular}

Pada siklus I ini dapat diketahui bahwa tingkat keterlaksanaan pembelajaran dari 16 langkah yang direncanakan hanya 11 langkah yang terlaksana. Sehingga persentase keterlaksanaan pembelajaran yang tercapai pada siklus ini sebesar $68,8 \%$ seperti yang tampak pada tabel 2. Pada siklus I 
berlangsung dilakukan observasi oleh guru bina sebagai observer. Hasil observasi direfleksikan bersama antara peneliti dan guru bina guna perbaikan pada siklus II.

Tabel 3. Hasil rekap nilai tes formatif (siklus I dan Siklus II)

\begin{tabular}{llllll}
\hline \multirow{2}{*}{ No } & \multirow{2}{*}{ Nama Siswa } & \multicolumn{3}{l}{ Siklus I } & \multicolumn{2}{l}{ Siklus II } & \\
\cline { 3 - 6 } & Silai & Tuntas & Nilai & Tuntas \\
\hline 1 & Sare'ah & 80 & Ya & 85 & Ya \\
2 & Meli Mulyana & 65 & Tidak & 75 & Ya \\
3 & Lia Rohani & 65 & Tidak & 75 & Ya \\
4 & Piati & 50 & Tidak & 70 & Tidak \\
5 & Liza Septi Arini & 55 & Tidak & 80 & Ya \\
6 & Julianti & 75 & Ya & 85 & Ya \\
7 & Hendriani & 60 & Tidak & 85 & Ya \\
Ketuntasan klasikal & $28.6 \%$ & & $85.7 \%$ & \\
\hline
\end{tabular}

Hal ini menyebabkan pembelajaran berjalan monoton. Hal ini berimplikasi pada hasil belajar siswa yang hanya mencapai ketuntasan klasikal $28.6 \%$ dari 5 soal yang diberikan pada siklus seperti tampak pada tabel 3. Pada siklus ini, 5 orang siswa nilainya amat rendah. Hal ini menunjukkan belum mencapai ketuntasan karena belum mencapai $85 \%$. Pada siklus I berlangsung dilakukan observasi oleh guru bina sebagai observer. Hasil observasi direfleksikan bersama antara guru bina untuk perbaikan pada siklus II.

Siklus II dilaksanakan pada Senin 23 mei 2016 dengan materi Keliling dan Luas Segitiga dengan alokasi waktu $2 \times 40$ menit sesuai dengan RPP yang telah disusun. Pada Pertemuan ini pembelajaran berjalan dengan cukup baik karena terjadi interaksi yang lebih banyak antara siswa dengan guru dan media selama pembelajaran dengan strategi kooperatif STAD. Pada siklus II ini dapat diketahui bahwa tingkat keterlaksanaan pembelajaran dari 16 langkah yang direncanakan mampu terlaksana 14 langkah Sehingga persentase keterlaksanaan pembelajaran yang tercapai pada siklus ini sebesar $85.7 \%$ seperti yang tampak pada tabel 3. Perbandingan peningkatan keterlaksanaan RPP dan Hasil belajar tiap siklus ditampilkan pada gambar 3 .

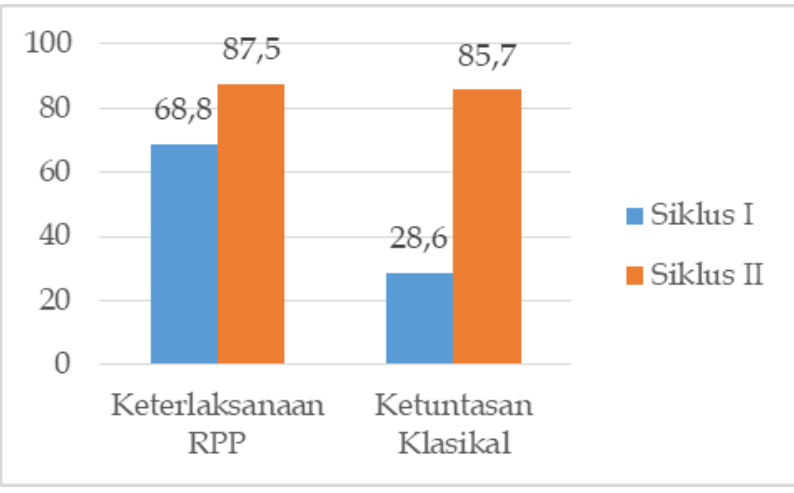

Gambar 3. Perbandingan Keterlaksanaan RPP dan Ketuntasan Klasikal

Meningkatnya persentase keterlaksanaan pembelajaran berimplikasi pada peningkatan hasil belajar. Hasil belajar siswa pada siklus II diperoleh dari hasil tes yang diberikan kepada siswa sebanyak 5 soal. Pada gambar 3 menunjukkan bahwa hasil belajar siswa pada siklus II meningkat menjadi $85.7 \%$ dan dinyatakan tuntas secara klasikal. Karena siswa yang memperoleh nilai yang diharapkan melebihi 85 \%. Berdasarkan refleksi terhadap hasil belajar mengajar yang sudah dilaksanakan pada siklus II, maka perlu dilakukan perbaikan-perbaikan terhadap kendala-kendala yang terjadi.

\section{Analisis hasil Implementasi}

Pemberian tindakan dalam penelitian ini berlangsung selama 2 siklus dengan sekali pertemuan (2 X 40 menit) dalam setiap siklus. Dari pengamatan terhadap proses pembelajaran yang dilakukan didapatkan permasalahan antara lain siswa kurang 
mengerti tentang pembelajaran menggunakan media Segitiga Bongkar Pasang. Dalam proses pembelajaran ada beberapa siswa yang sibuk sendiri dan membuat keramaian kelas. Disamping itu siswa tidak berani bertanya jika mengalami kesulitan. Selain itu karena terbiasa dengan proses pembelajaran yang lalu sehingga banyak yang bingung dan kurang mencermati penjelasan guru. Guru dalam menjelaskan bagian-bagian segitiga dan sudut segitiga dengan media segitiga dan strategi kooperatif STAD kurang optimal karena pada kegiatan-kegiatan guru yang ada dalam perencanaan belum dilakukan. Sehingga pada pertemuan berikutnya guru harus berusaha melakukan kegiatan-kegiatan pembelajaran yang sudah direncanakan.

Pada siklus II masalah-masalah tersebut sudah berkurang, yang ditunjukkan antara lain: siswa sudah berani bertanya kepada guru, siswa sudah terbiasa menempatkan diri dalam pembelajaran sehingga proses pelajaran lebih fokus. Hal ini terlihat dari peningkatan hasil pengamatan kegiatan guru dalam pembelajaran pada siklus II yaitu sebesar $85.7 \%$. Mengingat tujuan penelitian telah tercapai maka penerapan media Segitiga Bongkar Pasang dengan strategi kooperatif STAD dalam pembelajaran dikatakan dapat meningkatkan hasil belajar Matematika siswa kelas VII SMP Terbuka Narmada I TKB Mandiri Montong Buwuh II Lombok Barat Tahun Pelajaran 2015-2016.

Berdasarkan hasil penelitian yang dilakukan dengan Penelitian Tindakan Kelas (PTK) yang dilakukan selama dua siklus pembelajaran dapat diketahui bahwa terjadi peningkatan hasil belajar siswa menggunakan media Segitiga Bongkar Pasang dengan strategi kooperatif STAD. Hal ini ditunjukkan dari hasil belajar pada siklus I dan siklus II pada gambar 3. Peningkatan hasil belajar ini tidak lepas dari kegiatan siswa dalam mencoba media Segitiga Bongkar Pasang untuk mendapatkan sebuah temuan baru. Peningkatan hasil belajar tersebut juga sejalan dengan pendapat Gagne dalam (Dahar, 2011) bahwa penggunaan gambaran mental dalam mengungkapkan informasi baru, cukup membantu dalam proses mengingat informasi tersebut. Gambaran mental yang sangat bermanfaat untuk menggambarkan dimensidimensi yang abstrak dapat memperlancar pemahaman dan ingatan.

Disamping itu, mempelajari konsep melalui proses terlibat langsung dengan objek riil mempunyai beberapa kelebihan antara lain: (1) membantu siswa untuk memfasilitasi retensi belajar yang sangat baik sehingga mempermudah apabila terjadi proses mengingat kembali konsep tersebut di waktu yang akan datang, (2) membantu siswa dalam memperjelas pemahaman konsep-konsep abstrak yang secara umum disajikan dalam teori, (3) membantu siswa untuk membangun pengetahuan baru yang dapat digunakan sebagai dasar untuk proses pembelajaran berkelanjutan, (4) belajar melalui interaksi dengan objek riil yang dikombinasikan dengan kooperatif bermanfaat untuk membangun keterampilan sosial, belajar dalam sebuah kelompok dalam mengembangkan keterampilan pemecahan masalah, dan (5) dapat mendorong siswa untuk melakukan percobaan-percobaan lebih lanjut dan memperluas konsep ke penerapan yang lain.

\section{Analisis hasil Penerapan Media Segitiga Bongkar Pasang}

Produk penelitian ini yang berupa Media Segitiga Bongkar Pasang telah digunakan dalam proses pembelajaran. Media Segitiga Bongkar Pasang diimplementasikan dengan strategi kooperatif STAD ke peserta didik tanpa melalui metode Research and Development mengingat banyaknya penelitian serupa telah menunjukkan kelayakan Segitiga baik melalui uji ahli maupun melalui uji skala terbatas dan uji skala kecil. Setelah implementasi di kelas, kemudian dilakukan diseminasi dengan teman sejawat guru Bina SMP Terbuka Narmada I TKB Mandiri Montong Buwuh II Lombok Barat tanggal 27 Mei 2016. Hal ini dilakukan untuk 
memperkenalkan media Segitiga Bongkar Pasang untuk diketahui kemanfaatannya oleh khalayak lebih luas, terutama guru-guru Bina Matematika SMP Terbuka.

Pada desiminasi tersebut, peneliti mendapatkan banyak masukan dari rekan guru teman sejawat diantaranya: (1) Media Segitiga Bongkar Pasang bisa dipakai pada Materi Theorema Phytagoras; (2) Agar dibuatkan panduan penggunaan Alat.

\section{Kesimpulan}

Simpulan yang dapat diambil berdasarkan hasil Penelitian Tindakan Kelas menggunakan Media Segitiga Bongkar Pasang dengan strategi Kooperatif STAD adalah: (1) Media Segitiga Bongkar Pasang dapat menjelaskan jenis-jenis segitiga ditinjau dari panjang sisi dan besar sudutnya; (2) Kemampuan Media Segitiga Bongkar Pasang tidak hanya diterapkan pada materi Segitiga tetapi bisa pada materi lain; (3) Penerapan media Segitiga Bongkar Pasang dapat meningkatkan hasil belajar peserta didik pada materi Segitiga TKB Mandiri Montong Buwuh II; dan (4) Peningkatan hasil belajar peserta didik dengan menggunakan media Segitiga Bongkar Pasang berupa peningkatan sebesar $57.1 \%$ dimana Pada siklus I ketuntasan klasikal mencapai $28.6 \%$ sedangkan pada siklus II menjadi $85.7 \%$.

\section{Daftar Pustaka}

Dahar, R. (2011). Teori Belajar dan Pembelajaran. Erlangga.

Ibrahim. (2001). Media pembelajaran: Bahan sajian program pendidikan akta mengajar. FIP. UM.

Muhson, A. (2010). Pengembangan Media Pembelajaran Berbasis Teknologi Informasi. Jurnal Pendidikan Akuntansi Indonesia, $8(2)$. https://doi.org/10.21831/jpai.v8i2.949

Munzir, S. (2015). Peningkatan Kemampuan Penalaran Matematis dan Kemandirian
Belajar Siswa Madrasah Tsanawiyah (MTs) melalui Pendekatan Contextual Teaching and Learning (CTL). Jurnal Didaktik Matematika, 2(2), 59-71. https://doi.org/10.24815/dm.v2i2.2815

Setyosari, P., Dwiyogo, W. D., \& Malang, U. N. (2016). Strategi Guru dalam Membangun Lingkungan Belajar yang Kondusif : Studi Fenomenologi pada Kelas-kelas Sekolah Menengah Pertama di Ponorogo. Jurnal Pendidikan Dan Pembelajaran, 23(April), 10-19.

Sholihah, D. A., \& Mahmudi, A. (2015). Keefektifan Experiential Learning Pembelajaran Matematika MTs Materi Bangun Ruang Sisi Datar. Jurnal Riset Pendidikan Matematika, 2(2), 175. https://doi.org/10.21831/jrpm.v2i2.7332

Sukmadinata. (2005). Metode Penelitian Pendidikan. PT. Remaja Rosdakarya.

Sunain, S. (2016). Pengaruh Tingkat Pendidikan Orang Tua Terhadap Tingkat Kecerdasan dan Keaktifan Siswa dari Kelas Satu Sampai dengan Kelas Enam Pada Semester I. PEDAGOGIA: Jurnal Pendidikan, 6(2), 160. https://doi.org/10.21070/pedagogia.v6i2 .942

Sururuddin, M. (2016). Pengembangan Model Pembelajaran Berbasis Quantum Teaching untuk Siswa Kelas IV Sekolah Dasar. Jurnal Didika (Wahana Ilmiah Pendidikan Dasar), 1(2), 1-11.

Triani, D. (2014). Hubungan Penggunaan Media Pembelajaran Dengan Hasil Belajar Pkn Pada Siswa Kelas X Dan XI Di SMA Muhammadiyah 1 Banjarmasin. Jurnal Pendidikan Kewarganegaraan, 4(7), 530-536. 